\title{
Effects of different soil treatments on the development of Spongospora subterranea f. sp. subterranea in potato roots and tubers in the greenhouse
}

\author{
${ }^{\text {ab }}$ Kenedy Simango and ${ }^{a}$ Jacquie E. van der Waals* \\ ${ }^{\text {a }}$ Department of Plant and Soil Sciences, Private Bag X20, University of Pretoria, Hatfield, 0028, South Africa \\ ${ }^{\mathrm{b}}$ Biotechnology Research Institute, Scientific and Industrial Research and Development Centre (SIRDC), 1574 Alpes Road, \\ Hatcliffe, Harare, Zimbabwe \\ *E-mail: Jacquie.vanderWaals@up.ac.za
}

Telephone number: +2712420 4065

Fax. Number: +27124204558

\begin{abstract}
Powdery scab caused by Spongospora subterranea f. sp. subterranea (Sss) causes extensive losses in potato production systems globally. Two pot experiments were established in the greenhouse in summer 2013 and winter 2014 to evaluate the effectiveness of different soil chemicals, fumigant, amendments and biological control agents (BCAs) against Sss in the rhizospheric soil, potato roots and tubers. The study used visual assessment methods to assess the effect of treatments on root galling and zoosporangia production; and qPCR to measure Sss concentration in the soil and in the potato roots and tubers. All six soil treatments, namely metam sodium, fluazinam, ZincMax, calcium cyanamide, Biocult and a combination of Bacillus subtilis and Trichoderma asperellum recorded significantly $(\mathrm{P}<0.05)$ lower numbers of zoosporangia in the roots compared to the untreated control. The same effect was observed on the concentration of Sss DNA in the roots at tuber initiation. A more diverse picture was obtained when root gall scores at tuber initiation and Sss DNA in the rhizospheric soil at tuber initiation and harvesting were compared. Significant differences $(\mathrm{P}<0.05)$ were also noted in disease severity, disease incidence, and tuber yield between metam sodium, fluazinam, ZincMax, calcium cyanamide and the untreated control. Calcium cyanamide gave the highest tuber yield. The study demonstrated the potential of soil treatments such as metam sodium, fluazinam, ZincMax and calcium cyanamide in managing Sss in potatoes by reducing the pathogen both in the rhizospheric soil and the roots of the potato plant.
\end{abstract}

Key words: potato; powdery scab; soil amendments; biological control; Spongospora subterranea f. sp. subterranea; control; management 


\section{Introduction}

Spongospora subterranea (Wallr.) Lagerh. f. sp. subterranea Tomlinson (Sss), the causal pathogen of root membrane dysfunction, root hyperplasia (root galls) and powdery scab on tubers of potatoes (Falloon et al. 2015), produces resistant resting spores in sporosori, which can survive in the soil for long periods of time (Merz 2008). Sss poses a big challenge to potato production in that, once introduced into the soil either through contaminated seed or farm machinery, it becomes very difficult to control. Wilson (2016) estimated that the Australian potato processing industry loses $\mathrm{A} \$ 13.4$ million per annum due to powdery scab. The resilience of the plasmodiophorid resting spores has been attributed to the three-layered cell wall which is comprised of $25.1 \%$ chitin, more than $2.5 \%$ other carbohydrates, 33.6\% protein and more than 17.5\% lipids (Moxham and Buczaki 1983). The life cycle of the plasmodiophorids is composed of two phases (Braselton 1995; Harrison et al. 1997; Merz 2008; Kageyama and Asano 2009; Schwelm et al. 2015) and these are the sporangial (primary) and sporogenic (cytogenous/secondary) phases. In the sporangial phase, Merz (2008) described that numerous secondary zoospores are formed in compartments within thin walled zoosporangia.

Powdery scab disease has gained importance in potato production areas throughout the world, and this has been attributed to an increase in irrigated potato production, use of susceptible varieties, and the ban of use of mercurybased seed amendments (Wale 1987). Integrated powdery scab management has been proposed to be the only effective and sustainable way to manage the disease (Falloon 2008). This management strategy includes the use of less susceptible potato varieties, avoiding introducing Sss inoculum into clean soils through the use of disease free potato seed and disinfecting farm implements previously used in Sss infested fields. Field management, especially irrigation and fertilizer management, and cultural practices such as crop rotations with non-host species have been recommended.

Various soil amendments, chemicals and fumigants have been found to reduce powdery scab disease on potatoes (Braithwaite et al. 1994; Falloon et al. 1996; Jeger et al. 1996; Nielsen and Larsen 2003; Falloon 2008; Gilchrist et al. 2009; Thangavel et al. 2015). These can either be applied as seed treatments or in furrow soil treatments. Fungicides such as mancozeb, fluazinam, propineb and dichlorophen-Na reduced powdery scab when applied as seed treatments (Falloon et al. 1996). In furrow soil treatments have been found to be effective against soil borne Sss (Braithwaite et al. 1994; Falloon et al. 1996). Recently, Thangavel et al. (2015) showed that soil-applied fungicides slowed down pathogen development in the roots of the host plant resulting in less disease severity compared to the untreated control. Metam sodium, a soil fumigant, was also reported to reduce powdery scab when it was applied through irrigation water (Nachmias and Krikun 1988). Biological control agents (BCAs) have also been evaluated in powdery scab management. A study by Nielsen and Larsen (2003) on the effect of two Trichoderma harzianumbased biocontrol agents in tomato seedlings inoculated with Sss showed significantly reduced root infection by zoosporangia but this was not reflected in increased growth of shoots and roots of the tomato plant. Another study conducted by Gilchrist et al. (2009) did not find any significant differences in disease severity between four isolates of Trichoderma asperellum and the untreated control. 
The present study therefore investigated the effect of various soil chemicals, fumigant, amendments and BCAs, on Sss in the roots and powdery scab disease on tubers of potatoes to determine which soil treatment would give the best control of Sss. It is hypothesized that the various soil treatments can reduce Sss infection in the roots and powdery scab disease severity and incidence.

\section{Materials and Methods}

Study Site: Two experiments were carried out in the greenhouse at the University of Pretoria experimental farm. The temperature in the greenhouse was maintained between $20-25{ }^{\circ} \mathrm{C}$, with $16 \mathrm{~h}$ of light, whilst the relative humidity was between $45 \%$ - $60 \%$ throughout the growth cycle. The first experiment was planted in summer 2013 (November) and the repeat experiment was planted five months later during winter 2014 (April). .

Experimental Design: The experiment was laid out in a Randomized Complete Block Design (RCBD) with three replications. Each replication had six pots, of which three pots were harvested during tuber initiation for root gall scoring and pathogen quantification whilst the other three pots were harvested at maturity for tuber assessment. The treatments were as follows: fluazinam, metam sodium, Biocult, calcium cyanamide, ZincMax and a combination of Bacillus subtilis and Trichoderma asperellum (BS + TA) (Table 1). Untreated soil was used as control treatment. Loamy soil infested with Sss was collected from a farm in the Limpopo Province and potted. Sss DNA was extracted from the soil and conventional PCR and qPCR were conducted using specific Sss primers and probes, respectively, to confirm the presence and quantity of the Sss in the soil. A susceptible potato cultivar (Up-to-Date) was used.

Application methods of treatments: The required dosage per pot was calculated and is presented in Table 1. A 5-1 stock solution for 1000 pots was made up for each treatment. Five milliliters of Biocult stock solution was applied to the soil one week after planting. Five millilitres of Trichoderma asperellum was sprayed onto one tuber per pot before planting while $5 \mathrm{ml}$ of Bacillus subtilis was applied to the soil directly after planting; $1.57 \mathrm{~g}$ of calcium cyanamide was incorporated into the soil 10 days before planting. Five milliliters of stock solutions of fluazinam and ZincMax, respectively, were applied to the soil before planting. Five milliliters of metam sodium stock solution was applied to the soil 3 days before planting and the pots were then covered with plastic for 3 days. 
Table 1. Treatments used in the study and their respective dosage rates

\begin{tabular}{|c|c|c|}
\hline Treatment & Active ingredient & Dosage applied per pot \\
\hline 1. Biocult mycorrhizae & Trichoderma spp. + Mycorrhiza spp. & $\begin{array}{l}0.00063 \mathrm{~g} \text { per pot }(200 \mathrm{~g} / \mathrm{ha}) \text { applied through irrigation one } \\
\text { week after planting }\end{array}$ \\
\hline $\begin{array}{l}\text { 2. Bacillus subtilis and Trichoderma asperellum } \\
\text { (BS + TA) }\end{array}$ & Bacillus subtilis and Trichoderma asperellum & $\begin{array}{l}0.0063 \mathrm{ml} \text { of TA was sprayed onto one tuber per pot before } \\
\text { planting. } 0.0063 \mathrm{ml} \text { per pot }(2000 \mathrm{ml} / \mathrm{ha}) \text { of } \mathrm{BS} \text { was applied to } \\
\text { the soil directly after planting. }\end{array}$ \\
\hline 3. Calcium cyanamide & Calcium cyanamide & $\begin{array}{l}1.57 \mathrm{~g} \text { per pot }(500 \mathrm{~kg} / \mathrm{ha}) \text { incorporated into the soil } 10 \text { days } \\
\text { before planting }\end{array}$ \\
\hline 4. Control & - & Untreated soil \\
\hline 5. Fluazinam & Fluazinam & $0.013 \mathrm{ml}$ per pot $(4 \mathrm{l} / \mathrm{ha})$ applied to the soil before planting \\
\hline 6. Metam sodium & Metam sodium (thiocarbamate) & $\begin{array}{l}1.8 \mathrm{ml} \text { per pot }(600 \mathrm{l} / \mathrm{ha}) \text { applied to the soil three days before } \\
\text { planting }\end{array}$ \\
\hline 7. ZincMax & Organic complex of $130 \mathrm{~g} / \mathrm{l}$ zinc $+6.5 \mathrm{~g} / \mathrm{l}$ boron & $0.0095 \mathrm{ml}$ per pot $(3 \mathrm{l} / \mathrm{ha}$ ) applied to the soil before planting \\
\hline
\end{tabular}




\section{Planting and Sampling}

The pots $(20 \mathrm{~cm}$ top diameter $\times 15 \mathrm{~cm}$ base diameter $\times 16 \mathrm{~cm}$ height $)$ were filled half way with soil one sprouted tuber of potato cultivar Up-to-Date was placed on top of the soil and then the pots were filled up with soil. The soil was kept moist by watering each pot with $200 \mathrm{ml}$ of sterile water every second day. Sampling of rhizospheric soil was done 2 months after planting (tuber initiation) and at harvest. The rhizospheric soil was sampled by collecting soil attached to the roots and $1 \mathrm{~g}$ thereof per treatment was used for DNA extraction. Root samples were collected 2 months after planting (tuber initiation) whilst tubers were collected at harvesting for tuber lesion assessment.

\section{DNA Extraction and Polymerase Chain Reaction}

DNA from the different treatments was extracted from $1 \mathrm{~g}$ of rhizospheric soil and $1 \mathrm{~g}$ of root tissue using a ZR Soil Microbe DNA Kit ${ }^{\mathrm{TM}}$ (Zymo Research Corp., USA) according to the manufacturer's instructions. To confirm the presence of Sss in the rhizosphere and root tissue, a conventional PCR was carried out in a final volume of $50 \mu 1$ containing $75 \mathrm{mM}$ Tris- $\mathrm{HCl} \mathrm{pH} 8.8,20 \mathrm{mM}\left(\mathrm{NH}_{4}\right)_{2} \mathrm{SO}_{4}$ (Bioline, UK), $2.5 \mathrm{mM} \mathrm{MgCl} 2,200 \mu \mathrm{M}$ of each dNTP, 250 nM of each S. subterranea-specific primer (Sp01 (5'-ATT GTC TGT TGA AGG GTG-3') and Sp02 (5'-GGT TAG AGA CGA ATC AGA A-3') (Bulman and Marshall 1998), and 1U Taq polymerase (Bioline, UK). Two microliters of DNA template was added to each reaction. The following PCR reaction profile was followed: initial denaturation at $94{ }^{\circ} \mathrm{C}$ for $2 \mathrm{~min}$, followed by 35 cycles of melting $\left(94^{\circ} \mathrm{C}\right.$ for $30 \mathrm{sec}$ ), annealing ( $53{ }^{\circ} \mathrm{C}$ for $30 \mathrm{sec}$ ) and extension $\left(72{ }^{\circ} \mathrm{C}\right.$ for $45 \mathrm{sec}$ ) with a final cycle of $72{ }^{\circ} \mathrm{C}$ for $7 \mathrm{~min}$. The PCR product was run on a $1 \%$ agarose gel and stained with Roti-safe Gel Stain alongside a standard size marker (Hyper Ladder II, Bioline, London, UK).

\section{Real Time PCR}

Standards for qPCR were prepared using DNA extracted from suspensions with known sporeball concentrations (1, 10, 100, 1000 and 10000 and 100000 sporeballs per ml, respectively) as described by van de Graaf et al. (2003). The DNA was diluted with TE buffer to obtain a dilution series of DNA equivalent to $0.01,0.1,1,10$ and 100 sporeballs per $\mu \mathrm{l}$, which was then subsequently used to obtain a standard curve for use in estimating the concentration of the unknown samples.

The soil and tissue DNA was quantified using a ThermoScientific PikoReal qPCR machine using the protocol described by van de Graaf et al. (2003).

\section{Root Galling Score}

Root gall scoring was done according to van de Graaf et al. (2007), where $0=$ no root galls, $1=$ one or two root galls, $2=$ several galls, mostly small $(<2 \mathrm{~mm}$ in diameter $), 3=$ many galls, some $>2 \mathrm{~mm}$ in diameter, and $4=$ most major roots with galls, some or all $>4 \mathrm{~mm}$ in diameter.

\section{Zoosporangium Infection Assessment}

Root infection was assessed by microscopic examination using a method modified from Merz (1989). Ten roots per pot were cut from the crown region and thoroughly washed with running tap water, destained with destaining 
solution (ethanol/chloral hydrate/ $\mathrm{H}_{2} \mathrm{O}-1: 1: 1 / \mathrm{w} / \mathrm{w} / \mathrm{w}$ ) for $10 \mathrm{~min}$, stained with a staining solution (3\% formaldehyde, $3.5 \%$ phenol, $6 \%$ lactic acid, $87.2 \%$ ethanol/water and $0.3 \%$ water blue; all w/w) for $5 \mathrm{~min}$ and then fixed with lactic acid for 5 min (Merz 1989). Root samples (of which five per pot were root hairs) were then examined microscopically at 100x magnification (Zeiss 195-041847 compound microscope; West Germany). Zoosporangia scoring was rated using the following scale: $0=$ no zoosporangia; $1=$ only a few zoosporangia on roots; $2=3-5$ roots with zoosporangia; $3=6-9$ roots with zoosporangia, moderate infection; $4=>10$ roots with zoosporangia, heavy infection (Merz 1989).

\section{Tuber Powdery Scab Assessment}

Disease incidence (DI), disease severity (DS), yield and tuber number was determined on the harvested tubers. Disease incidence was calculated by dividing the total number of infected tubers by the total number of harvested tubers and expressed as a percentage. Any tuber with a powdery scab lesion was considered infected. As for DS, all tubers from each pot were individually assessed for powdery scab using a standard disease assessment key derived by Falloon et al. (1995), where 0 was no disease symptoms and 10 was when a tuber was completely covered with powdery scab lesions. The efficacy of the treatments on powdery scab disease was calculated using a method described by Smith et al. (1984):

The efficacy of the treatments on powdery scab disease $=\frac{\text { DS untreated soil }-D S \text { treated soil }}{D S \text { untreated soil }} \times 100 \%$.

\section{Statistical analyses}

A combined nested analysis of variance (ANOVA) was used to test for differences between the effects of seven different treatments applied in the RCBD that was repeated twice. Means of the three pots used per replicate were first calculated before analysis. Means were compared using the Tukey LSD test at the 5\% level (Snedecor and Cochran, 1980). Data were analysed using the statistical program GenStat@ (Payne, 2015).

\section{RESULTS}

Results from the conventional PCR indicated that the soil collected from a field in the Limpopo province of South Africa was indeed contaminated with Sss. The quantity of Sss in the soil used in both experiments before planting was found to be $0.0091 \mathrm{ng} \mathrm{DNA} / \mathrm{g}$ of soil. No meaningful interaction was found between repeat of the experiment, therefore the nested combination analysis was applied to the data.

\section{Root Galling Score}

Scoring for root galls and zoosporangia was done 2 months after planting (tuber initiation stage). All treatments except BS + TA had a significantly lower $(\mathrm{P}<0.05)$ number of root galls than the untreated control. Plants grown in soil treated with metam sodium had the lowest number of root galls followed by those grown in soil treated with fluazinam, ZincMax and calcium cyanamide (Table 2). 


\section{Zoosporangium Infection Assessment}

Significant differences $(\mathrm{P}<0.05)$ were recorded in the number of zoosporangia among soil treatments (Table 2). The metam sodium treatment recorded the lowest number of zoosporangia followed by fluazinam and ZincMax whilst the untreated control had the highest number of zoosporangia.

Table 2. Root gall scores (0-4) and zoosporangia scores (0-10) in different soil treatments measured at tuber initiation

\begin{tabular}{l|l|ll}
\hline Treatment & $\begin{array}{l}\text { Average root gall scores for two } \\
\text { experiments }\end{array}$ & $\begin{array}{l}\text { Average zoosporangia scores for two } \\
\text { experiments }\end{array}$ \\
\hline Biocult & $1.3 \mathrm{~b}$ & $2.3 \mathrm{~b}$ & \\
BS + TA & $1.7 \mathrm{a}$ & $2.6 \mathrm{~b}$ & \\
Calcium cyanamide & $1.0 \mathrm{c}$ & $2.3 \mathrm{~b}$ & \\
Control & $1.8 \mathrm{a}$ & $4.0 \mathrm{a}$ & \\
Fluazinam & $0.7 \mathrm{~d}$ & $1.5 \mathrm{c}$ & \\
Metam sodium & $0.4 \mathrm{e}$ & $1.2 \mathrm{c}$ & \\
ZincMax & $1.0 \mathrm{c}$ & $1.7 \mathrm{c}$ & \\
\hline SEM & 0.05 & 0.15 & \\
Significance & $\mathrm{P}<0.05$ & $\mathrm{P}<0.05$ & \\
\hline
\end{tabular}

Means followed by different letters within each column indicate significant differences $(\mathrm{P}<0.05)$ between soil treatments according to Tukey's LSD test at the 95\% confidence level. BS + TA = Bacillus subtilis and Trichoderma asperellum.

\section{Quantification of Sss in the Potato Roots and Soil}

At harvest, a higher quantity of Sss DNA in the rhizospheric soil was recorded in all treatments than at tuber initiation (Figure 1). Soil treated with Biocult had significantly lower $(\mathrm{P}<0.05)$ Sss DNA concentrations at tuber initiation compared to the control and metam sodium. At harvest, however, soil treated with metam sodium and fluazinam had significantly $(\mathrm{P}<0.05)$ lower Sss DNA compared to the control and BS + TA. 


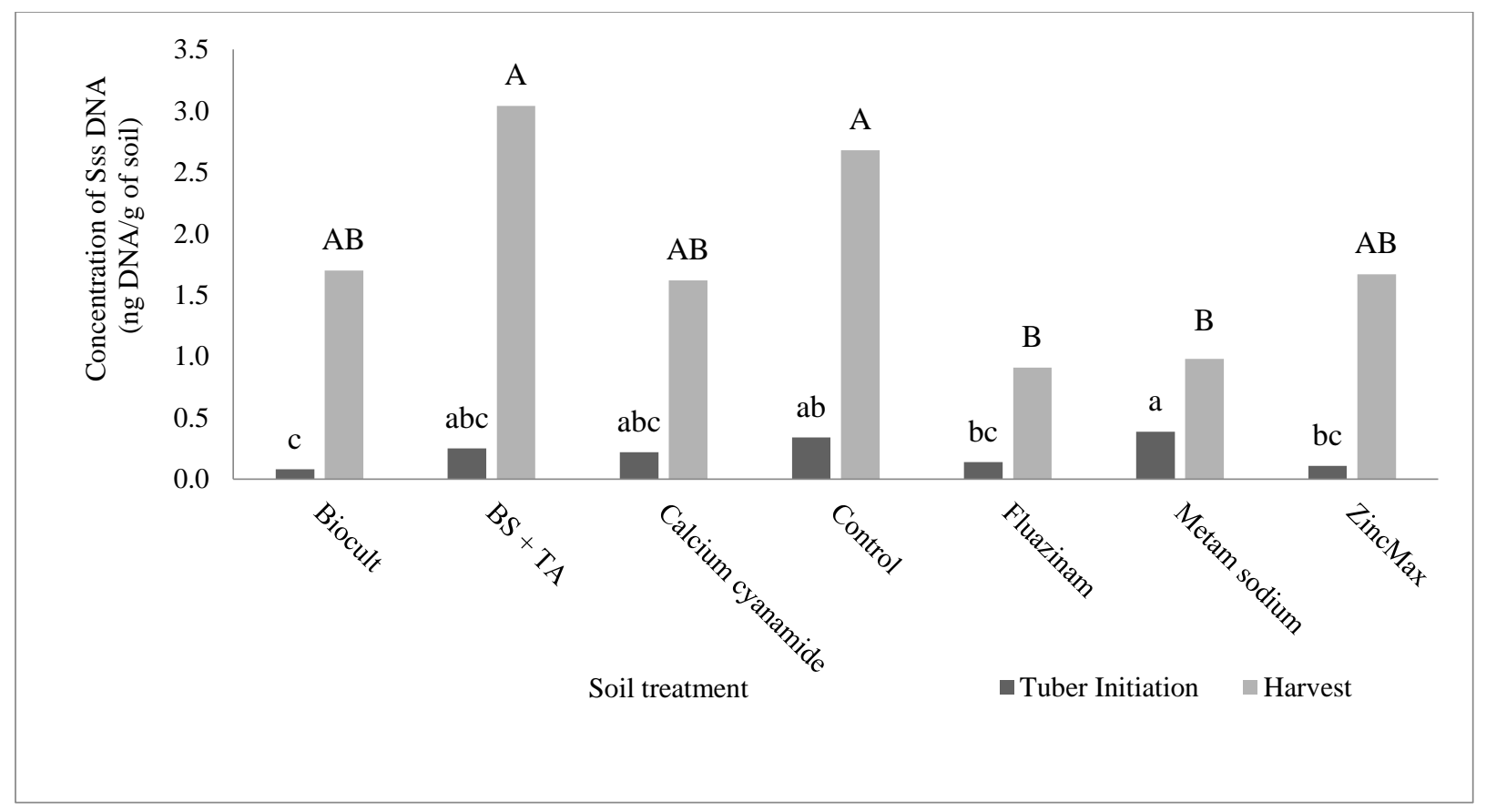

Figure 1. Concentration of Spongospora subterranea f. sp. subterranea DNA in the rhizospheric soil at tuber initiation and harvest in different soil treatments. Bars with different letters (small letters for tuber initiation stage and capital letters for harvest) indicate significant differences according to Tukey's LSD test at the 95\% confidence level BS + TA $=$ Bacillus subtilis and Trichoderma asperellum.

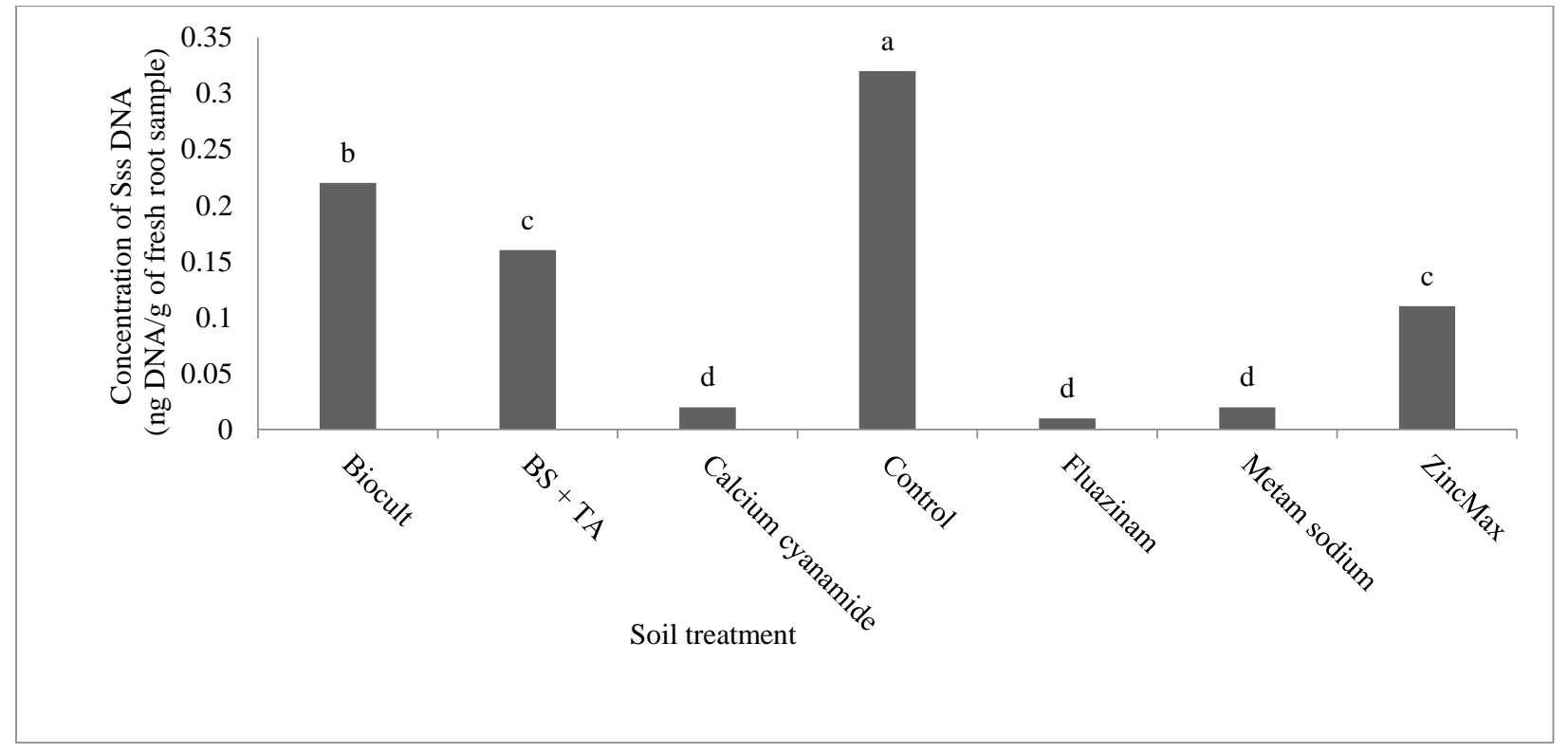

Figure 2. Concentration of Spongospora subterranea f. sp. subterranea DNA in the roots of potato cultivar Up-to-Date at tuber initiation in different soil treatments. Bars with different letters indicate significant differences according to Tukey's LSD test at the $95 \%$ confidence level. BS + TA = Bacillus subtilis and Trichoderma asperellum. 


\section{Tuber Powdery Scab Assessment}

Soil treatments metam sodium, fluazinam, ZincMax and calcium cyanamide were not significantly different $(\mathrm{P}<$ $0.05)$ in terms of DS. The control treatment had a significantly $(P<0.05)$ higher DS compared to all soil treatments except Biocult and BS + TA (Figure 3).

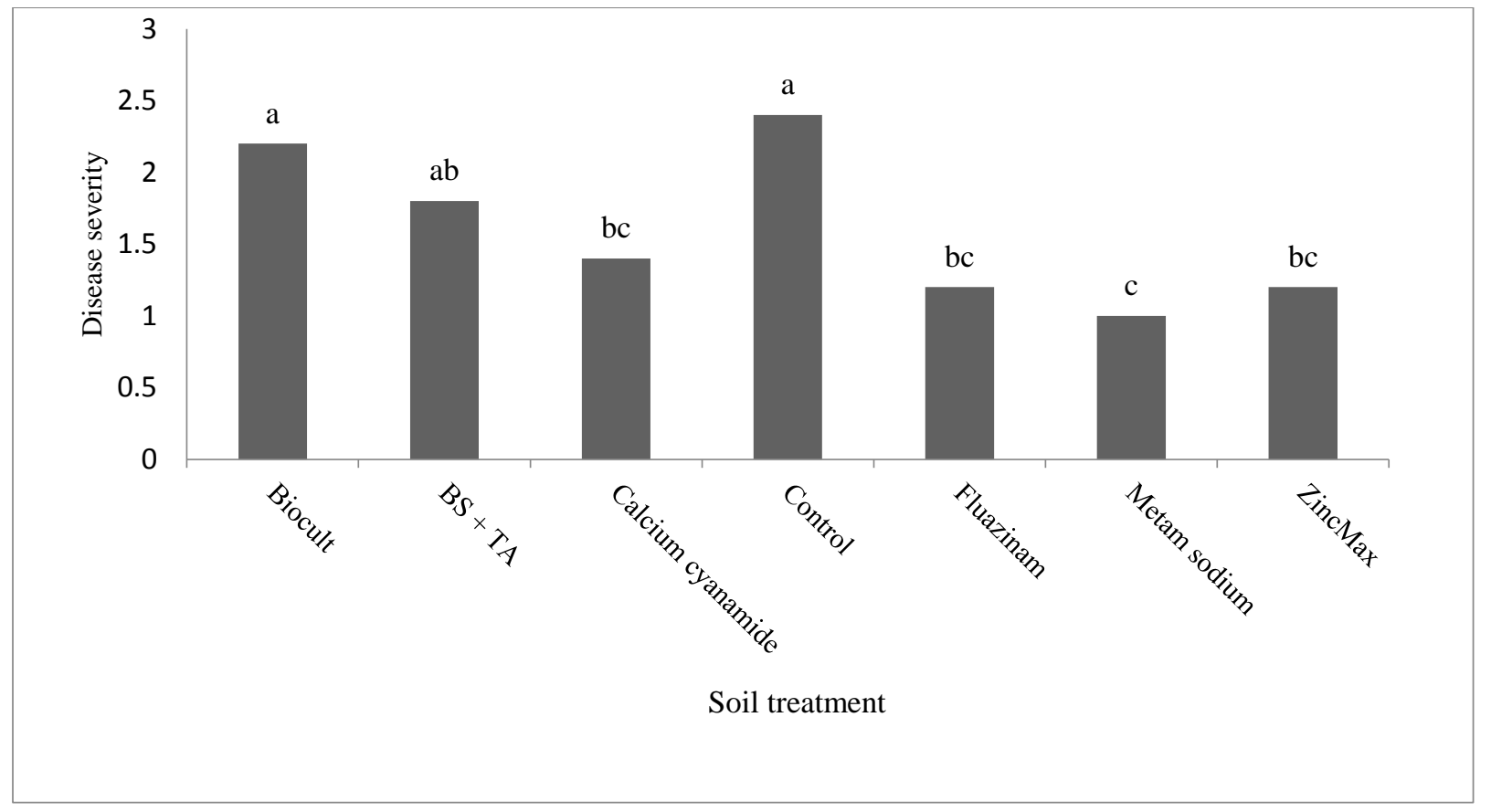

Figure 3: Powdery scab disease severity of potato cultivar Up-to-Date under different soil treatments. Bars with different letters indicate significant differences according to Tukey's LSD test at the $95 \%$ confidence level between treatments. $\mathrm{BS}+\mathrm{TA}=$ Bacillus subtilis and Trichoderma asperellum.

DI ranged from $17.8 \%$ to $70 \%$ (Figure 4). The lowest DI was found in the soil treated with calcium cyanamide which was not significantly different $(\mathrm{P}<0.05)$ from metam sodium, fluazinam and ZincMax. The BS + TA treatment resulted in the highest DI and was not significantly different from the control (Figure 4). The efficacy of the soil treatments in reducing powdery scab disease severity ranged from $8 \%$ to $58 \%$. The treatment which had the lowest efficacy was Biocult (8\%) followed by BS + TA (25\%), calcium cyanamide (41\%), ZincMax (50\%), fluazinam $(50 \%)$ and metam sodium $(58 \%)$. Significant $(\mathrm{P}<0.05)$ negative correlations were obtained between DS and yield $\left(r^{2}=-0.90\right)$ and between DI and yield $\left(r^{2}=-0.85\right)$. 


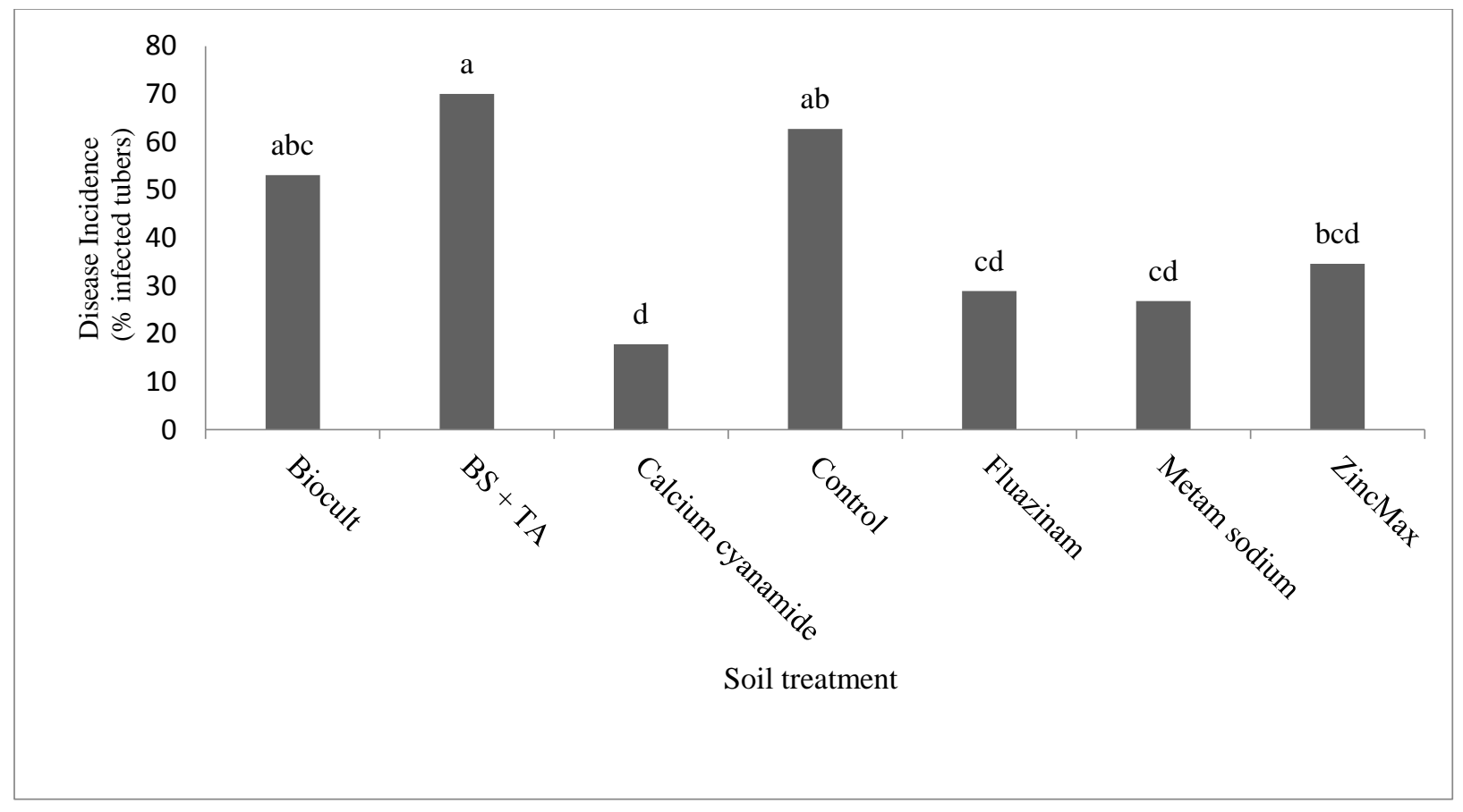

Figure 4: Powdery scab disease incidence (percentage infected tubers) of potato cultivar Up-to-Date under different soil treatments. Bar graphs with different letters indicate significant differences according to Tukey's LSD test at the 95\% confidence level between treatments. BS + TA = Bacillus subtilis and Trichoderma asperellum.

\section{Yield}

Yield of potato variety Up-to-Date was significantly different $(\mathrm{P}<0.05)$ amongst the soil treatments used in the study. Soil treated with calcium cyanamide gave the highest yield of $250.7 \mathrm{~g}$ per treatment which was significantly different $(\mathrm{P}<0.05)$ from the control, Biocult, BS + TA and ZincMax (Table 3).

\section{Tuber Number}

The number of tubers per treatment were significantly different $(\mathrm{P}<0.05)$ amongst the treatments used in the study. The highest number of tubers was recorded in soil treated with calcium cyanamide which was significantly different $(\mathrm{P}<0.05)$ from the control, Biocult, BS + TA and ZincMax (Table 3). 
Table 3: Number of tubers and tuber yield (g) per treatment of potato cultivar Up-to-Date planted in soil infested with Spongospora subterranea f. sp. subterranea Sss

\begin{tabular}{lll}
\hline Treatment & No. of Tubers per plant & Tuber Yield (g per plant) \\
\hline Biocult & $9.6 \mathrm{bc}$ & $160.9 \mathrm{c}$ \\
BS + TA & $7.4 \mathrm{c}$ & $148.8 \mathrm{c}$ \\
Calcium cyanamide & $19.9 \mathrm{a}$ & $250.7 \mathrm{a}$ \\
Control & $10.4 \mathrm{bc}$ & $165.8 \mathrm{c}$ \\
Fluazinam & $15.5 \mathrm{ab}$ & $216.9 \mathrm{ab}$ \\
Metam sodium & $12.2 \mathrm{abc}$ & $216.4 \mathrm{ab}$ \\
ZincMax & $10.9 \mathrm{bc}$ & $181.3 \mathrm{bc}$ \\
\hline SEM & 1.7 & 10.3 \\
Significance & $\mathrm{P}<0.05$ & $\mathrm{P}<0.05$
\end{tabular}

Means followed by different letters within each column indicate significant differences according to Tukey's LSD test at the 95\% confidence level between treatments. BS + TA = Bacillus subtilis and Trichoderma asperellum.

\section{Discussion}

The work presented in this study provides an understanding of the efficacy of various soil chemicals, fumigant, amendments and BCAs in decreasing Sss in the rhizospheric soil, roots and tubers of the potato plant. The loamy soil used in the study was collected from a field from which powdery scab diseased potatoes were harvested. The study was carried out in pots in a greenhouse using a potato cultivar susceptible to both root and tuber infection (results not shown). The use of a single potato cultivar and a controlled environment in this study also limited the effects of genotype $\times$ environment interaction. Testing of the soil by qPCR showed adequate inoculum levels for infection of potato plants (van de Graaf et al. 2005). Several studies on Sss have been carried out in greenhouses. However, many of these studies have focused on screening the susceptibility of potato cultivars to Sss (Falloon et al. 2003; Houser and Davidson 2010; Maldonado et al. 2013). The researchers reported that the greenhouse evaluation of the susceptibility of potato cultivars to Sss generally indicated the field response to powdery scab (Falloon et al. 2003; Houser and Davidson 2010; Perla et al. 2014). Greenhouse studies have also been carried out on the effect of boron on clubroot of canola (Deora et al. 2012) and the effect of plant growth promoting formulations on clubroot of two Brassica species (Kammerich et al. 2014). Deora et al. (2012) reported similarities between results obtained from controlled and field studies on some of the experiments whilst other experiments did not show a strong correlation between controlled and field studies. Although the results from this greenhouse study cannot be extrapolated directly to the field, they provide an indication of treatments which may hold potential for management of Sss in the field.

In this study, various soil treatments reduced disease severity and incidence on potato cultivar Up-to-Date by reducing infection in the roots of the host. The sporangial stage in the life cycle of Sss is one of the most important stages as it provides an opportunity for Sss to rapidly proliferate (Merz 2008), subsequently leading to higher 
infection of the host plant and inoculum build up in the soil. This is the stage where numerous secondary zoospores are formed and produce biflagellate secondary zoospores which exit the host and initiate further infection cycles (Harrison 1997; Merz 2008). Therefore, any soil treatment that significantly suppresses formation of zoosporangia or affects zoospore mobility could reduce disease severity and incidence of powdery scab, and inoculum build up in the soil.

Metam sodium is a soil fumigant which is converted to methyl isothiocyanate molecules (Zheng et al. 2006), which have biocidal properties (Wales 2000). The isothiocyanate molecules might have reduced the activity of zoospores or killed some of the zoospores leading to lower zoospore numbers compared to the control. Reports on the efficacy of metam sodium on powdery scab disease have also been made by Nachmias and Krikun (1988). Fluazinam, a soil fungicide which belongs to the pyridinamine group, probably reduced the zoosporangia in the potato roots by inhibiting the germination of the resting spores or by reducing the rate at which the zoosporangia multiplied, leading to fewer zoosporangia in the roots compared to the control. Previously, fluazinam has been reported to reduce powdery scab disease incidence and severity in potatoes (Burgess et al. 1992, Braithwaite et al. 1994 and Falloon et al. 1996). Fluazinam has been reported to completely prevent sporangium formation and reduce the duration of zoospore motility and germination of encysted zoospores of Phytophthora capsici, P. citrophthora, and P. parasitica (Matheron and Porchas 2000).

Amending the soil's chemical composition through the use of ZincMax and calcium cyanamide also reduced the number of zoosporangia in the roots compared to the untreated control. ZincMax contains $130 \mathrm{~g} / \mathrm{l}$ zinc and $6.5 \mathrm{~g} / \mathrm{l}$ boron. Salts of zinc have been reported to reduce powdery scab disease in the field (Wale 1987; Burgess et al. 1992) whilst boron (as sodium tetraborate) also reduced Sss root infection of tomato plants when it was applied in a nutrient solution (Falloon et al. 2001). In his review on the role of micronutrients in disease resistance, Dordas (2008) said zinc has been reported in most cases to reduce disease severity in plants possibly due to its toxic effects on the pathogen. Zinc also kills zoospores, as demonstrated by Tomlinson (1958) with S. subterranea f. sp. nasturtii in watercrest. Boron's role in reducing disease severity could either be through its function in cell wall structure, cell membrane permeability, stability, or in metabolism of phenolics or lignin (Blevins and Lukaszewski 1998; Brown et al. 2002). In another related study, boron suppressed the development of Plasmodiophora brassicae from plasmodia to further stages thereby reducing the number of zoospores released from root hairs and limiting the development of cortical infection (Webster and Dixon 1991).

Calcium cyanamide, which is a nitrogenous fertilizer, is hydrolyzed to urea, calcium hydroxide and unstable intermediate cyanide compounds (Buchanan and Barsky 1930). These cyanide compounds might have been toxic to resting spores and zoosporangia consequently leading to lower root infection compared to the control. Calcium cyanamide has been reported to have fungicidal properties which control soil borne diseases such as clubroot caused by Plasmodiophora brassicae in cabbage, in Brussel sprouts (Dixon and Wilson 1983) and in cauliflower (Tremblay et al. 2005), Verticillium wilt of eggplant caused by Verticillium dahliae Kleb (Blestos 2005) and inhibited the growth of Rhizoctonia solani Kuhn, Fusarium oxysporum f. sp. fragariae (Fof) and Verticillium dahliae in Petri dishes (Lijing et al. 2007). 
The BCAs Biocult and a combination of Bacillus subtilis and Trichoderma asperellum also recorded lower numbers of zoosporangia in the roots of potato cultivar Up-to-Date compared to the control. The BCAs might have suppressed Sss through parasitism, antagonism, induced resistance or through antibiosis (Lo 1998, Junaid et al. 2013). The mode of action of BS has been reported to be through antibiosis and induced resistance in canola against P. brassicae (Lahlali et al. 2013). The efficacy of BCAs on Sss has been reported by Nielsen and Larsen (2003) in roots of tomatoes but a study by Gilchrist et al. (2009) reported insignificant differences between four Trichoderma spp. and untreated control.

The lower zoosporangial activity in the roots of potatoes planted in soil treated with various soil treatments might have led to fewer root galls and tuber lesions. Lower root gall numbers have also been reported by Thangavel et al. (2015) in soil treated with fluazinam compared to the control. Quantification of Sss in the rhizospheric soil at tuber initiation has shown that the suppressed zoospore activity and lower root galls in various treatments led to lower Sss concentration in the treated soil compared to the untreated control. It is important not only to measure tuber lesions and root infection but DNA concentration in the soil as well, as this provides a more comprehensive view of the effects of the various soil treatments on the pathogen's life cycle.

The efficacy of the various treatments against powdery scab ranged from $8 \%$ to $58 \%$. The lower DS and DI noted with the soil treatments metam sodium, fluazinam, calcium cyanamide and ZincMax has shown the efficacy of these treatments in suppressing Sss. However, there is a need to investigate ways of improving the efficacy of these various treatments by optimizing their application times such that they coincide with peaks in zoospore release in the life cycle of Sss.

Sss has been reported to reduce the productivity of the plant by affecting the root system (Nielsen and Larsen 2003; Falloon et al. 2004; Lister et al. 2004; Falloon et al. 2015). In this study, significant negative relationships were obtained between DS and yield, and DI and yield confirming that Sss reduces plant productivity. The higher yield in the soil treated with calcium cyanamide might have been due to both the urea which is released by calcium cyanamide and the fungicidal property of the soil treatment. Soil amendments calcium cyanamide, metam sodium and fluazinam consistently gave a higher yield in the two experiments compared to the control treatment. Similar results have been reported where soil treatments such as mancozeb, fluazinam, propineb and dichlorophen-Na led to an increased marketable yield of potato compared to the control (Falloon et al. 1996).

In conclusion, chemicals, fungicides and amendments may prove to be useful in reducing Sss both in the soil and plant tissues. Fluazinam, metam sodium, ZincMax and calcium cyanamide have shown potential to reduce the pathogen in the soil and the roots of the host plant. However, the efficacy of these treatments against Sss was not complete, therefore the use of these various treatments must be integrated with other management strategies such as the planting of less susceptible potato cultivars, long term crop rotations with non-hosts or zoosporangial hosts and reduction of irrigation during tuber initiation. There is still a need to carry out further studies on the modes of action of these treatments, especially the BCAs. 


\section{Acknowledgements}

We acknowledge the National Research Foundation (NRF), South Africa, and Potatoes South Africa for financial support. The NRF is also acknowledged for purchasing the DNA sequencing instrument (grant UID: 78566) used at the University of Pretoria. However, opinions expressed and conclusions arrived at, are those of the authors and are not necessarily to be attributed to the NRF. The authors thank Ms MF Smith from stats4science, for statistical advice.

\section{References}

Blestos FA (2005) Use of grafting and calcium cyanamide as alternatives to methyl bromide soil fumigation and their effects on growth, yield, quality and Fusarium wilt control in melon. J Phytopathol 153:155-161

Blevins DG, Lukaszewski KM (1998) Boron in plant structure and function. Ann Rev of Plant Physiol 49:481-500

Braithwaite M, Falloon RE, Genet RA, Wallace AR, Fletcher JD, Braam WF (1994) Control of powdery scab of potatoes with chemical seed tuber amendments. N Z J Crop Hort Sci 22:121-8

Braselton JP (1995) Current status of the Plasmodiophorids. Crit Rev Microbiol 21:263-275

Brown PH, Bellaloui N, Wimmer MA, Bassil ES, Ruiz J, Hu H, Pfeffer H, Dannel F, Romheld V (2002) Boron in plant biology. Plant Biol 4:205-223

Buchanan GH, Barsky G (1930) The hydrolysis and polymerization of cyanamide in alkaline solutions. J Am Chem Soc $52(1): 195-206$

Bulman SR, Marshall JW (1998) Detection of Spongospora subterranea in potato tuber lesions using the polymerase chain reaction (PCR). Plant Pathol J 47 (6):759-766

Burgess PJ, Burnett FJ, Brereton PS, Wale SJ, Sinclair AH (1992) An overview of the influence of zinc on the severity of powdery scab in potatoes. Asp Appl Biol 33:143-50de Haan EG, van den Bovenkamp GEW (2005) Improved diagnosis of powdery scab (Spongospora subterranea f. sp. subterranea) symptoms on potato tubers (Solanum tuberosum L.) Potato Res 48:1-14

Deora A, Gossen BD, Walley F, McDonald MR (2011) Boron reduces development of clubroot in canola. Can J Plant Pathol 33 (4):475-484

Dixon GR, Wilson F (1983) Evaluation of calcium cyanamide for control of Plasmodiophora brassicae (clubroot). Ann Appl Biol 102:50-51

Dordas C (2008) Role of nutrients in controlling plant diseases in sustainable agriculture. A review. Agron Sustain Dev 28:33-46 
Falloon RE (2008) Control of powdery scab of potato: Towards an integrated disease management. Am J Potato Res $85: 253-260$

Falloon RE, Curtin D, Lister RA, Butler RC (2004) The obligate soilborne pathogen. Spongospora subterranea affects host (Solanum tuberosum). In Ophelkeller K, Hall B, eds. Proceedings of the $3^{\text {rd }}$ Australasian Soilborne Diseases Symposium. Adelaide, Australia: South Australian Research and Development Institute, $30-1$

Falloon RE, Genet RA, Wallace AR, Butler RC (2003) Susceptibility of potato (Solanum tuberosum) cultivars to powdery scab (caused by Spongospora subterranea f. sp. subterranea), and relationship between tuber and root infection. Australas Plant Pathol 32:377-385

Falloon RE, Merz U, Butler RC, Curtin D, Lister RA, Thomas SM (2015) Root infection of potato by Spongospora subterranea: Knowledge review and evidence for decreased plant productivity. Plant Pathol 10:1-13

Falloon RE, Merz U, Curtin D, Butler RC (2001) Boron affects Spongospora subterranea infection of host roots; laboratory and glasshouse results. In: Porter I, de Boer D, Cahill D, Edwards J, Hollaway G, Irwin J, Falloon RE, OphelKeller K, Magarey R, Smith I (eds) Proceedings of the 2nd Australasian soilborne diseases symposium, Victoria, Australia, March 5-8, pp 101-102

Falloon RE, Viljanen-Rollinson SLH, Coles GD, Poff JD (1995) Disease severity keys for powdery and downy mildews of pea, and powdery scab of potato. N Z J Crop Hort Sci 23:31-37

Falloon RE, Wallace AR, Braithwaite M, Genet RA, Nott HM, Fletcher JD, Braam WF (1996) Assessment of seed tuber, in furrow and foliar chemical amendments for control of powdery scab (Spongospora subterranea f.sp. subterranea) of potato. N Z J Crop Hort Sci 24:341-353

Gilchrist E, Villegas SJ, Reynaldi S (2009) Effect of powdery scab on four isolates of the fungus Trichordema asperellum in three types of soils. Rev Fac Nal Agr Medellin 62 (1):4783-4792

Harrison JG, Searle RJ, Williams NA (1997) Powdery scab of potato - a review. Plant Pathol J 46:1-25

Houser AJ, Davidson RD (2010) Development of a greenhouse assay to evaluate potato germplasm for susceptibility to powdery scab. Am Potato J 87:285-298

Jeger ML, Hide GA, van den Boogert PHJF, Termoshuizen AJ, van Baarlen P (1996) Pathology and control of soil borne fungal pathogens of potato. Potato Res 39:437-69

Junaid JM, Dar NA, Bhat TA, Bhat AH, Bhat MA (2013) Commercial biocontrol agents and their mechanism of action in the management of plant pathogens. Int J Modern Plant and Anim Sci 1(2):39-57.

Kageyama K, Asano T (2009) Life cycle of Plasmodiophora brassicae. J Plant Growth Regul 28:203-211 
Kammerich J, Beckmann S, Scharafat I, Ludwig-Müller J (2014) Suppression of the clubroot pathogen Plasmodiophora brassicae by plant growth promoting formulations in roots of two Brassica species. Plant Pathol 63:846-857

Lahlali R, Peng G, Gossen BD, McGregor L, Yu FQ, Hynes RK, Hwang SF, McDonald MR, Boyetchko SM (2013) Evidence that biofungicide Serenade (Bacillus subtilis) suppresses clubroot on canola via antibiosis and induced resistance. Phytopath 103:245-54

Lijing W, Tongle H, Lijing J, Keqiang C (2007) Inhibitory efficacy of calcium cyanamide on the pathogens of replant diseases in strawberry. Front Agric China 1 (2):183-187

Lister RA, Falloon RE, Curtin D, Butler RC (2004) Spongospora subterranea reduces host (Solanum tuberosum) growth. In: Ophelkeller K, Hall B, eds. Proceedings of the $3^{\text {rd }}$ Australasian Soilborne Diseases Symposium. Adelaide, Australia: South Australian Research and Development Institute, 135-6

Lo CT (1998) General mechanisms of action of microbial biocontrol agents. Plant Pathol Bulletin 7:155-166

Maldonado HML, Falloon RE, Butler RC, Conner AJ, Bulman SR (2013) Spongospora subterranea root infection assessed in two potato cultivars differing in susceptibility to tuber powdery scab. Plant Pathol 62:1089-1096

Matheron ME, Porchas M (2000) Impact of azoxystrobin, dimethomorph, fluazinam, fosetyl-Al, and metalaxyl on growth, sporulation, and zoospore cyst germination of three Phytophthora spp. Plant Dis 84:454-458

Merz U (1989) Infectivity, inoculum density and germination of Spongospora subterranea resting spores: a solution-culture test system. European Plant Protection Organization Bulletin 19:585-92

Merz U (2008) Powdery scab of potato - occurrence, life cycle and epidemiology. Am Potato J 85:241-246

Moxham SE, Buczacki ST (1983) Chemical composition of the resting spore wall of Plasmodiophora brassicae. Trans Br Mycol Soc 80:297-304

Nachmias A, Krikun J (1988) Etiology and control of powdery scab of potato in a semi-arid region of Israel. Phytoparasitica 16:33-38

Nielsen SL, Larsen J (2003) Two Trichorderma harzianum-based bio-control agents reduce tomato root infection with Spongospora subterranea (Wallr) Lagerh., f.sp. subterranea, the vector of Potato Mop Top Virus. Zeitschr Pflanzensch 111:145-150

Payne RW (2014) (Ed.) Introduction to GenStat ${ }^{\circledR}$ for Windows $^{\mathrm{TM}}$ (18 ${ }^{\text {th }}$ Edition), VSN International, Hemel Hempstead, Hertfordshire, UK. (c) VSN International.

Perla V, Jayanty SS, Holm DG, Davidson D (2014) Relationship between tuber storage proteins and tuber powdery scab resistance in potato. Am Potato J 91:233-245 
Schwelm A, Fogelqvist J, Knaust A, Jülke S, Lilja T, Bonilla-Rosso G, Karlsson M, Shevchenko A, Dhandapani V, Choi SR, Kim HG, Park JY, Lim YP, Müller JL, Dixelius C (2015) The Plasmodiophora brassicae genome reveals insights in its life cycle and ancestry of chitin synthesis. Sci Rep 5:1-14

Smith PG, Rodrigues LC, Fine PEM (1984) Assessment of the protective efficacy of vaccines against common diseases using Case-Control and Cohort Studies. Int J Epidemiol 13 (1):87-93

Snedecor GW, Cochran WG (1980) Statistical methods ( $7^{\text {th }}$ Ed.). Ames: Iowa State University Press, p 234

Thangavel T, Tegg RS, Wilson CR (2015) Monitoring Spongospora subterranea development in potato roots reveals distinct infection patterns and enables efficient assessment of disease control methods. PLoS ONE 10(9): e0137647. doi:10.1371/ journal.pone.0137647

Tomlinson JA (1958) Crook root of watercress. Ann App Bio 46:608-621

Tremblay N, Bélec C, Coulombe J, Godin C (2005) Evaluation of calcium cyanamide and liming for control of clubroot disease in cauliflower. Crop Prot 24:798-803

van de Graaf P, Lees AK, Cullen DW, Duncan JM (2003) Detection and quantification of Spongospora subterranea in soil, water and plant tissue samples using real time PCR. Eur J Plant Pathol 109:589-597

van de Graaf P, Lees AK, Wale SJ, Duncan JM (2005) Effect of soil inoculum level and environmental factors on potato powdery scab caused by Spongospora subterranea. Plant Pathol J 54:22-28

van de Graaf P, Wale SJ, Lees AK (2007) Factors affecting the incidence and severity of Spongospora subterranea infection and galling in potato roots. Plant Pathol J 56:1005-1013

Wale SJ (1987) Powdery scab - are there any easy options? Potato World 4:8-9

Wales PC (2000) Evaluation of methyl isothiocyanate as a toxic air contaminant. California Department of Pesticide Regulation. Department of the California Environmental Protection Agency, Sacramento, CA

Ward LI, Beales PA, Barnes AV, Lane CR (2004) A real-time PCR assay based method for routine diagnosis of Spongospora subterranea on potato tubers. J Phytopathol 152:633-638

Wesbster MA, Dixon GR (1991) Boron, $\mathrm{pH}$ and inoculum concentration influencing colonization by Plasmodiophora brassicae. Mycol Res 95:74-79

Wilson CR (2016) Plant pathogens - the great thieves of vegetable value. Acta Hortic 1123:7-16

Wright J, Lees AK, Van der Waals JE (2012) Detection and eradication of Spongospora subterranea in mini tuber tunnels. S Afr J Sci $108(5 / 6): 1-4$

Zheng W, Yates SR, Papiernik SK, Nunez J (2006) Conversion of metam sodium and emission of fumigant from soil columns. Atmos Environ 40:7046-7056 